\title{
Minireview: algal natural compounds and extracts as antifoulants
}

\author{
Mahasweta Saha $^{1,2} \cdot$ Franz Goecke $^{3} \cdot$ Punyasloke Bhadury $^{4}$
}

Received: 11 February 2017 /Revised and accepted: 17 October 2017 / Published online: 6 November 2017

(C) The Author(s) 2018

\begin{abstract}
Marine biofouling is a paramount phenomenon in the marine environment and causes serious problems to maritime industries worldwide. Marine algae are known to produce a wide variety of chemical compounds with antibacterial, antifungal, antialgal, and anti-macrofouling properties, inhibiting the settlement and growth of other marine fouling organisms. Significant investigations and progress have been made in this field in the last two decades and several antifouling extracts and compounds have been isolated from microand macroalgae. In this minireview, we have summarized and evaluated antifouling compounds isolated and identified from macroalgae and microalgae between January 2010 and June 2016. Future directions for their commercialization through metabolic engineering and industrial scale up have been discussed. Upon comparing biogeographical regions, investigations from Southeast Asian waters were found to be
\end{abstract}

The original version of this article was revised due to a retrospective Open Access order.

Mahasweta Saha

sahamahasweta@gmail.com

1 Benthic Ecology, Helmholtz Center for Ocean Research, Düsternbrooker weg, 24105 Kiel, Germany

2 Present address: School of Biological Science, University of Essex, Colchester, CO 43 SQ, UK

3 Department of Plant and Environmental Science (IPV), Norwegian University of Life Sciences (NMBU), Ås, Norway

4 Integrative Taxonomy and Microbial Ecology Research Group, Department of Biological Sciences, Indian Institute of Science Education and Research Kolkata, Mohanpur, Nadia, West Bengal 741246, India rather scarce. Thus, we have also discussed the need to conduct more chemical ecology based research in relatively less explored areas with high algal biodiversity like Southeast Asia.

Keywords Algae $\cdot$ Biofouling $\cdot$ Natural products . Antifouling defense $\cdot$ Antibacterial $\cdot$ Anti-diatom . Anti-macrofouling

\section{Introduction}

Marine biofouling - the colonization and growth of microand macro-organisms on any submerged surface (living and man-made structures) is paramount in the marine environment (Wahl 1989). An average milliliter of natural seawater contains $10^{6}$ cells of bacteria, $10^{3}$ microalgae, and $10^{2}$ propagules of algae and benthic invertebrate larvae (Harder 2009) making any undefended surface quite likely to be colonized by microand macro-foulers. Uncontrolled biotic coverage is heavily detrimental for efficient operation and functioning of such submerged man-made structures (reviewed in Maréchal and Hellio 2009; Callow and Callow 2011). Biofouling on structures like ships not only increase ownership costs but are also accompanied with environmental pollution through increased emission of gases like carbon dioxide, carbon monoxide, and sulfur dioxide (Chambers et al. 2006) and is also involved with transport of invasive species (Gollasch 2002). Remediation of biofouling on ship hulls only costs approximately $€ 120$ billion per year (Chapman et al. 2014). To counter such detrimental effects, biofouling was previously controlled using toxic antifouling coatings. While the use of antifouling compounds like tributlyl tin (TBT) and copper oxide have been found to be the most effective method, their non- 
targeted effect on other marine organisms like toxicity, imposex, bioaccumulative effect, and contamination of the food chain (Fernández-Alba et al. 2002; Bellas 2006;) has led to a total ban of TBT-based coatings in 2008 by the International Maritome Organization. Although new biocide formulations like irgarol, chlorothalonil, dichlofluanid, and diuron were introduced in marine antifouling AF coatings and initially thought to be environment friendly, later they were reported to be toxic, accumulating in marinas and harbors (Chapman et al. 2014). The ban of TBT and other toxic $\mathrm{AF}$ coatings has drawn a huge amount of interest towards bioinspired AF approaches, i.e., the investigation of novel, environment-friendly AF compounds from organisms that are mostly free from foulers colonizing their surfaces. Latest strategies towards development of environment-friendly AF coatings included biomimetic approaches, "biomimicry" (reviewed by Scardino and de Nys 2011), and incorporation of natural antifouling compounds into marine paints (Chambers et al. 2006). However, for their potential application in industries, such compounds must be cost effective in terms of production, long lasting, easy to use, and non-toxic to marine biota (Ralston and Swain 2009). Efforts made and the systems tested till date have not been enough successful as they failed to meet all or partly the criteria stated above since such compounds are usually not stable once exposed to the natural environment (Maréchal and Hellio 2009); making them durable is a current challenge. Also, development of a natural product is time consuming and a rigorous process. Further, their non-toxicity towards non-target species needs to be assured before being deployed in the field.

Benthic marine environments are quite diverse and characterized by extreme competition for light, space, nutrient, and other resources (Wahl 2009). Space being a limiting factor all potential benthic organisms are also confronted and colonized by micro and macro settlers - a phenomenon typically termed as epibiosis when the substrate involved is a living one (Wahl 1989). As epibiosis is usually detrimental to the (basibiont) host (Wahl 2008), many basibionts have developed either a physical or chemical (or both) protection mechanism against such colonizers, either by themselves (reviewed by Da Gama et al. 2014) or through symbiotic relationships with bacterial epibionts (reviewed by Singh et al. 2015). Over the past 25 years, several investigations have reported many natural antifouling compounds being extracted and characterized from varied marine prokaryotes and eukaryotes in assays against relevant fouling organisms and a number of excellent reviews reporting their potential use as antifouling compounds have been published (reviewed by Fusetani 2011; Dobretsov et al. 2013; Puglisi et al. 2014; Qin et al. 2013).

Being sessile and restricted to the photic zone, macroalgae offer optimal growth conditions to many epibiotic organisms (Harder 2008). Their three-dimensional structure also offers a large surface area for settlement in benthic marine habitats (Seed 1985). Thus, macroalgae are highly susceptible to epibiosis in comparison to other potential basibionts. Macroalgae have evolved efficient defense mechanisms as a mean of protection and thus have been found to be producers of wealth of antifouling compounds (reviewed by Bhadury and Wright 2004; Da Gama et al. 2014). Unlike macroalgae, microalgae are not susceptible to colonization by macroepibionts, but they also experience intense competition for space and other resources with their neighbors. Certain microalgae are known to control their microenvironment through the employment of allelochemicals which have been suggested to be responsible for observed patchy distribution in species composition around these microalgae (Saburova et al. 1995; Borowitzka 2016). Such synergistic and antagonistic ecological interactions through employment of chemicals have triggered interest among marine natural product chemists leading to the examination of numerous natural products as a possible basis for novel anti-biofilm compounds like cyanogen bromide produced by Nitzschia cf. pellucida (Vanelslander et al. 2012).

In the last 5 years, a large number of macroalgal species ( 89 species in total) and few microalgal species (13 species in total) have been tested for antifouling activity and several metabolites have been isolated with related bioactivity. The scope of the current review is to cover their activity against maritime fouling and not medical and industrial fouling. In this review, we have summarized the current status of marine algal antifouling compounds and extracts isolated and identified between January 2010 and June 2016. We also present current challenges and future perspectives on development of antifouling strategies from marine algae. Currently, there is an important amount of information on metabolic routes, physiological responses, and algal cultivation, and there are an increasing number of studies on algal genomics (Radakovits et al. 2010; Ai et al. 2015; Hlavová et al. 2015; Perez Garcia and Bashan 2015) which, when grouped together, we consider essential for the development of algal biotechnology. For a potential sustainable development of natural algae-related antifouling strategies, we have two main focuses: (a) the use of available and upcoming genomic information to understand biofouling from the algal genomic perspective (we present the case of diatom genes linked to biofilm formation) and thereby develop gene knock-out-based (or modification) antifouling strategies and (b) it is necessary to couple screening, isolation of compounds, and the genomic studies with industrial upscaling and metabolic engineering for a sustainable commercial production of natural micro algal compounds. Also, summing up all the ecologically and industrially relevant antifouling investigations, it is noteworthy that the majority of investigations have focused on algae from temperate waters despite the fact that tropical waters are rich in biodiversity. Therefore, in this review, we have highlighted the importance 
of expanding the area of sampling to still un-explored zones (we present Southeast Asia as a case study) with chemical ecology research objectives, i.e., isolating and testing natural compounds in ecologically relevant bioassays.

\section{Antifouling compounds from macroalgae}

Apart from being the major primary producers in temperate ecosystems and the largest biomass producers in marine environment, macroalgae produce a diverse array of natural compounds as mode of protection against natural enemies (Goecke et al. 2010). Over the last 5 years, a number of studies (some of which are discussed below) have reported new antifouling compounds from macroalgal extracts like the cystophloroketals and chromanols, along with an increasing number of reports of activities from crude extracts of different polarities (Table 1, Fig. 1).

Certain genera, like the red algae Asparagopsis and Laurencia, and the brown alga Sargassum continue to be source of new active antifouling compounds. Asparagopsis spp. belong to the order Bonnemaisoniales, which is known to be a rich source of halogenated bioactive compounds (Jha et al. 2013). Recent study of the introduced red alga Asparagopsis taxiformis collected from the Indian Ocean has led to the discovery of two new highly brominated cyclopentenones: mahorone and 5-bromomahorone with antimicrobial activity against both marine and terrestrial microbes (Greff et al. 2014). Another investigation on the same species, collected from the intertidal region of the Arabian Sea and Bay of Bengal, has found the methanolic extract to have anti-quorum sensing activity (Jha et al. 2013). Other seaweed species have also been shown to produce quorum-sensing inhibitors (Carvalho et al. 2017). Members of the genus Laurencia (Ceramiales) are also known to be a rich source of halogenated secondary metabolites (Blunt et al. 2009) and they continue to be source of new compounds. Recently, a new omaezallene and four new polyether triterpenoids with anti-macrofouling activity have been discovered from Laurencia sp. and Laurencia viridis, respectively (Umezawa et al. 2014; Cen-Pacheco et al. 2015).

Brown algae of the genus Cystoseira (Fucales) are known to be good source of bioactive terpenoid derivates, specially meroterpenoids and diterpenoids (reviewed by Gouveia et al. 2013). A monocyclic meroditerpenoid isolated from Cystoseira tamariscifolia has shown high potential for inhibition of common foulers like Balanus amphitrite and Mytilus edulis. Cystophloroketals A and B from the same alga have shown high inhibition activity against two species of fouling microalgae and moderate antimicrobial activity against a range of bacteria, fungi, and microalgae (Hattab et al. 2015). Along with the reported role of pholorotannins as antifoulants from certain fucoid species, certain metabolites like fucoxanthin and dimethylsulfoniopropionate (DMSP), which were previously considered to have just primary functions, have been reported to function as regulators of the microbial density and composition over Fucus vesiculosus (Lachnit et al. 2013; Saha et al. 2011, 2012, 2014). Identified compounds with AF activity are provided in Fig. 2.

Furthermore, many other studies have investigated the activities of both polar and non-polar extracts and reported antibacterial, antimicroalgal, and antifungal properties from a variety of algae belonging to the genera Caulerpa, Chondrus, Dictyota, Padina, Sargassum, and Ulva (Chambers et al. 2011; Cho 2013; Ktari et al. 2010; Silva et al. 2013, see Table 1).

In terms of number of species, more than a quarter of the studies involved red macroalgae and the remaining two third was composed of brown and green seaweeds (Fig. 1). In terms of the chosen bioactivity, most of the studies demonstrated an antimacrofouling activity (e.g., Maréchal and Hellio 2011; Van Alstyne et al. 2014) followed by antibacterial (e.g., Silva et al. 2013; Natrah et al. 2015) and antimicroalgal activity (e.g. Silkina et al. 2012; Sun et al. 2015). This may be based on the fact that, space being limited in the benthic environment, macrofoulers usually tend to settle on macroalgal surfaces thereby selecting for antimacrofouling defenses. Also, epibacterial colonization is ubiquitous on algal surfaces with the ability to negatively impact macroalgal fitness (Wahl et al. 2012) thereby selecting for antibacterial defenses.

\section{Antifouling compounds from dinoflagellates, diatoms, and other marine microalgae}

Several studies have been conducted to investigate the products of microalgal metabolism, not only to understand its nature but also to search for substances with possible applications to humans in different fields of interest (de De Morais et al. 2015). Some of the earliest and most extensive research on microalgal secondary metabolites has been on cyanobacteria, dinoflagellates (Dinophyceae), a few other microflagellates, and diatoms (Bacillariophyceae) (Garcia Camacho et al. 2007). This is because of the ability of certain bloom-forming species to produce structurally quite diverse toxins like brevetoxins produced by Karenia brevis (Fig. 3). Such bloom phenomena by toxic microalgae are generally known as harmful algal blooms (HABs). HABs can be highly toxic to humans and other animals and have further dramatic health and socio-economic impacts (Pearson et al. 2010; Clément et al. 2016; Mazard et al. 2016).

Different species from divergent phylogenetic orders of the dinoflagellates produce phytotoxins, e.g., Alexandrium spp. and Protoceratium spp. (Gonyaulacales), Azadinium sp. (Dinophyceae incertae sedis), Dinophysis spp. (Dinophysiales), Gymnodinium spp. and Karenia spp. 
Table 1 Antifouling compounds and extracts from macroalgae

\begin{tabular}{|c|c|c|c|c|}
\hline Source & Biogenic compound(s)/type of extract & Bioactivity & Origin & Reference \\
\hline Asparagopsis taxiformis ${ }^{\mathrm{RHO}}$ & $\begin{array}{l}\text { Mahorone } \\
\text { 5-bromomahorone }\end{array}$ & $\mathrm{AB}$ & Mayotte & Greff et al. 2014 \\
\hline Asparagopsis taxiformis ${ }^{\mathrm{RHO}}$ & Methanolic extract & $\mathrm{AB}, \mathrm{QSD}$ & India & Jha et al. 2013 \\
\hline Bonnemaisonia hamifera ${ }^{R H O}$ & 1,1,3,3-Tetrabromo-2-heptanone ${ }^{2}$ & $\mathrm{ABF}$ & Sweden & Persson et al. 2011 \\
\hline Caulerpa prolifera ${ }^{\mathrm{CHL}}$ & Ethanol and methanol extracts & $\mathrm{AB}$ & Brazil & Silva et al. 2013 \\
\hline Ceramium botryocarpum $^{\mathrm{RHO}}$ & Ethanol fraction & AA & France & Silkina et al. 2012 \\
\hline Ceramium rubrum $^{\mathrm{RHO}}$ & Dichloromethane extract & $\mathrm{AF}$ & Chile & Cortés et al. 2014 \\
\hline Chondrus crispus ${ }^{\mathrm{RHO}}$ & $\begin{array}{l}\text { Toluene-soluble } \\
\text { crude ethanolic extract }\end{array}$ & $\mathrm{ABF}$ & Ireland & Salta et al. 2013 \\
\hline Chondrus crispus ${ }^{\mathrm{RHO}}$ & Crude ethanol extracts & $\mathrm{AA}, \mathrm{AB}$ & Ireland & Chambers et al. 2011 \\
\hline Cladophora clavuligera $^{\mathrm{CHL}}$ & Methanolic and dichloromethane extract & $\mathrm{AB}$ & India & Bragadeeswaran et al. 2011a \\
\hline Cystoseira tamariscifolia $^{\mathrm{PHE}}$ & Cystophloroketals A-B & $\mathrm{AA}, \mathrm{AB}, \mathrm{AF}$ & Algeria & Hattab et al. 2015 \\
\hline Cystoseira tamariscifolia $^{\mathrm{PHE}}$ & monocyclic meroditerpenoid & $\mathrm{AMF}$ & Algeria & Hattab et al. 2015 \\
\hline Dictyota spp. ${ }^{P H E}$ & Diterpenes, glicerol derivatives & $\mathrm{AB}, \mathrm{AF}$ & France & Othmani et al. 2014 \\
\hline Dictyota fasciola $^{\mathrm{PHE}}$ & Dichloromethane and methanol extract & $\mathrm{AA}, \mathrm{AB}, \mathrm{AMF}$ & Tunisia & Ktari et al. 2010 \\
\hline Dictyosphaeria ocellata $^{\mathrm{CHL}}$ & Methanol extract & $\mathrm{AB}, \mathrm{ABF}$ & USA & Sneed and Pohnert 2011a, b \\
\hline Fucus vesiculosus $^{\mathrm{PHE}}$ & Fucoxanthin $^{3}$, dimethyl sulphopropionate ${ }^{4}$, proline $^{5}$ & $\mathrm{AB}, \mathrm{ABF}$ & Germany & $\begin{array}{l}\text { Saha et al. 2011, 2012, } \\
\text { Wahl et al. 2010, } \\
\text { Lachnit et al. 2013 }\end{array}$ \\
\hline Gracilaria edulis $^{\mathrm{RHO}}$ & Isoamyl alcohol extract & $\mathrm{AB}$ & India & Rajan et al. 2015 \\
\hline Hypnea musciformes ${ }^{\mathrm{RHO}}$ & Ethanol and methanol extracts & $\mathrm{AB}$ & Brazil & Silva et al. 2013 \\
\hline Laurencia johnstonii $^{\mathrm{RHO}}$ & Ethly ether extract & $\mathrm{AA}, \mathrm{AB}, \mathrm{AF}$ & Mexico & Águila-Ramírez et al. 2012 \\
\hline Laurencia sp. ${ }^{\mathrm{RHO}}$ & $\begin{array}{l}\text { Omaezallene }^{6} \\
\text { intricatetraol }^{7}\end{array}$ & $\mathrm{AMF}$ & Japan & Umezawa et al. 2014 \\
\hline Laurencia translucida ${ }^{\mathrm{RHO}}$ & Fatty acid derivatives & AMF & Brazil & Paradas et al. 2016 \\
\hline Laurencia viridis ${ }^{\mathrm{RHO}}$ & $\begin{array}{l}\text { 28-Hydroxysaiyacenol B } \\
\text { Saiyacenol C } \\
\text { 15,16-epoxythyrsiferol A } \\
\text { 15,16-Epoxythyrsiferol B }\end{array}$ & AMF & Spain & Cen-Pacheco et al. 2015 \\
\hline Padina gymnospora ${ }^{\mathrm{PHE}}$ & Ethanol and methanol extracts & $\mathrm{AB}$ & Brazil & Silva et al. 2013 \\
\hline Sargassum horneri ${ }^{\mathrm{PHE}}$ & Chromanols $^{8}$ & $\mathrm{AA}, \mathrm{AB}, \mathrm{AMF}$ & South Korea & Cho 2013 \\
\hline Sargassum muticum $^{\mathrm{PHE}}$ & Galactoglycerolipids & $\mathrm{AB}, \mathrm{AF}, \mathrm{AMF}$ & France & Plouguerné et al. 2010b \\
\hline Sargassum muticum $^{\mathrm{PHE}}$ & Ethanol fraction & AA & France & Silkina et al. 2012 \\
\hline Sargassum polyceratium ${ }^{\mathrm{PHE}}$ & Hexane extract & $\mathrm{AB}$ & Martinique & Thabard et al. (2011) \\
\hline Sargassum wightii ${ }^{\mathrm{PHE}}$ & Methanol extract & $\mathrm{AB}$ & India & Bragadeeswaran et al. 2011b \\
\hline Sargassum vulgare ${ }^{\mathrm{PHE}}$ & Unidentified polar compounds & $\mathrm{AMF}$ & Brazil & Plouguerné et al. 2012 \\
\hline Sargassum vulgare ${ }^{\mathrm{PHE}}$ & $\begin{array}{l}\text { Hexane extracts } \\
\text { methanol and dichloromethane extracts } \\
\text { polyphenolic extracts }\end{array}$ & $\mathrm{AA}, \mathrm{AB}, \mathrm{AMF}$ & Brazil & Plouguerné et al. 2010a \\
\hline Sphaerococcus coronopifolius ${ }^{\mathrm{RHO}}$ & Bromosphaerol $^{9}$ & AMF & Greece & Piazza et al. 2011 \\
\hline Taonia atomaria $^{\mathrm{PHE}}$ & $\begin{array}{l}\text { sesquiterpenes } \\
\text { polyunsaturated fatty acids }\end{array}$ & $\mathrm{AB}, \mathrm{AMF}$ & France & Othmani et al. 2015 \\
\hline Ulva fasciata $^{\mathrm{CHL}}$ & Ethanol and methanol extracts & $\mathrm{AB}$ & Brazil & Silva et al. 2013 \\
\hline Ulva intestinalis ${ }^{\mathrm{CHL}}$ & Hexane extract & $\mathrm{AB}$ & Thailand * & Srikong et al. 2015 \\
\hline Ulva lactuca ${ }^{\mathrm{CHL}}$ & Ethyl ethanol extract & $\mathrm{AA}, \mathrm{AB}, \mathrm{AF}$ & Mexico & Águila-Ramírez et al. 2012 \\
\hline Ulva pertusa ${ }^{\mathrm{CHL}}$ & Alkaloids, phenolic acid & AA & China & Sun et al. 2015 \\
\hline Ulvaria obscura $^{\mathrm{CHL}}$ & Dopamine & $\mathrm{AA}, \mathrm{AMF}$ & USA & Van Alstyne et al. 2014 \\
\hline 8 spp. macroalgae ${ }^{\text {CHL,PHE,RHO }}$ & Methanol extract & $\mathrm{AB}$ & Malaysia* & Natrah et al. 2015 \\
\hline 11 spp. macroalgae ${ }^{\text {CHL,PHE,RHO }}$ & Polar and non-polar extracts & QSD & Brazil & Batista et al. 2014 \\
\hline 30 spp. macroalgae ${ }^{\mathrm{CHL}, \mathrm{PHE}, \mathrm{RHO}}$ & Diverse aqueous and organic extracts & $\mathrm{AMF}$ & France & Maréchal and Hellio 2011 \\
\hline
\end{tabular}

The bioactivities are the following: antibacterial activity $(\mathrm{AB})$, antifungal (AF), anti-microalgal including diatoms and cyanobacteria (AA), antimacrofouling including mollusks (AMF), quorum sensing disruptor (QSD), and anti-biofilm (ABF). Also the algae groups: Chlorophyta (CHL), Phaeophyceae (PHE), and Rhodophyta (RHO). Studies made in Southeast Asia are highlighted with an asterisk. 1-9= compounds listed in Fig. 2

(Gymnodiniales), and Prorocentrum spp. (Prorocentrales), and diatoms as well as Pseudonitzschia spp. (Bacillariales). Such diversity is magnified at a rich subspecies level, and in consequence, the heterogeneity of associated phycotoxins and its derivatives are quite variable and big (Orr et al. 2013). The production of such toxins has been seen as an ecological advantage since the release of those chemicals into the environment may deter, inhibit growth, or kill competing species and predators (Caroppo and Pagliara 2011; Ma et al. 2011; PoulsonEllestad et al. 2014; Rolton et al. 2014; Bagwell et al. 2016). 
Fig. 1 Bioactivity of metabolites or extract fractions from a total of 24 species of red algae, 13 species of green algae, and 18 species of brown algae, active against marine relevant species during the period 2010-2016. Antibacterial activity (AB), antifungal (AF), anti-microalgal including diatoms and cyanobacteria (AA), antimacrofouling including mollusks and crustacean (AMF), quorum sensing disruptor (QSD), toxins (TX), and anti-biofilm (ABF)
Marine macroalgae spp.

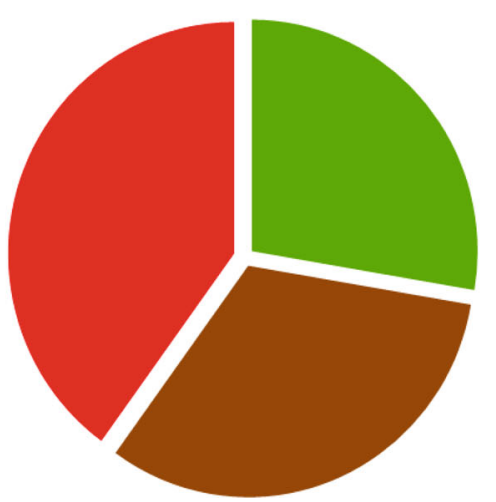

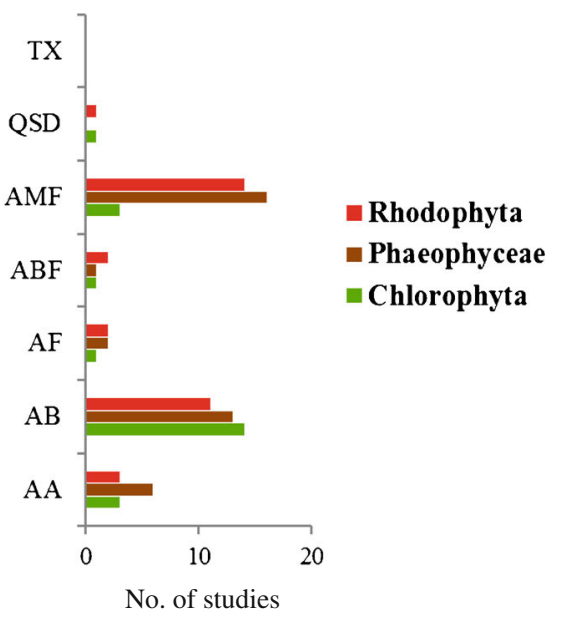

Allelopathic interactions between microalgal species also may contribute to the formation and succession of red tides (Cai et al. 2014). As the interactions with many potential foulers are regulated by chemical cues, there is a high potential in the identification and use of such compounds for biotechnological applications like antifouling compounds.

With respect to other microalgae groups, in the last decade, most of the studies had focused on the content of fatty acids and pigments aiming for their use in biotechnology, e.g., carotenoids and polyunsaturated fatty acids (PUFAs) for feed, and as active ingredients for cosmetics, among others (Abida et al. 2013; Borowitzka 2013a). Even though green microalgae are generally regarded safe for human consumption, there is still a knowledge gap in understanding the metabolic and biochemical potential of these algae (Bagwell et al. 2016).<smiles>[2H]C1C(=O)C(Br)=C(Br)C1(O)C(Br)Br</smiles>

(1) 5-bromomahorone $\mathrm{R}=\mathrm{Br}$<smiles>CCCCC(Br)(Br)C(=O)C(Br)Br</smiles>

(2) 1,1,3,3- tetrabromo-2-heptanone
Between January 2010 and June 2016, only 14 relevant studies were conducted on marine microalgal species, which tested extracts against other marine organisms. Only few compounds (e.g., fatty acids) were isolated from diatoms and dinoflagellates which have demonstrated antimicrobial or antifouling activities (Desbois et al. 2010). Although the number of isolated compounds is clearly less than in cyanobacteria (data not shown), the potential exists to increase that number, because most of these studies have reported bioactivity of diverse cultures and their organic extracts but did not isolate the active compounds as yet (Table 2).

In terms of number of species, half of the studies involved dinoflagellates and most of the second half was composed of diatoms. Only one study incorporated a marine haptophyte, and thus, many other microalgal groups remain unstudied (Fig. 4). In terms of the chosen bioactivity, most of the studies
(3) Fucoxanthin

(4) DMSP

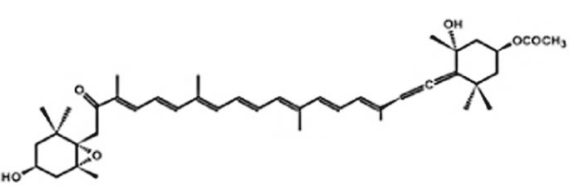<smiles>C[SH](C)CCC(=O)O</smiles><smiles>O=C(O)C1CCCN1</smiles>

(5) Proline<smiles>CC/C(Br)=C/C=C/C(O)C(Br)C1(Br)OC(C=C=CBr)CC1O</smiles>

(6) Omaezallene

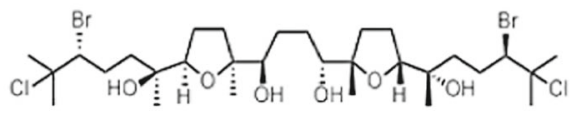

(7) Intricatetraol<smiles>CC(=CCCCCCC(C)C(C)O)CCCC(C)C(C)O</smiles>

(8) Chromanol 
Fig. 3 Brevetoxins from microalgae Karenia brevis

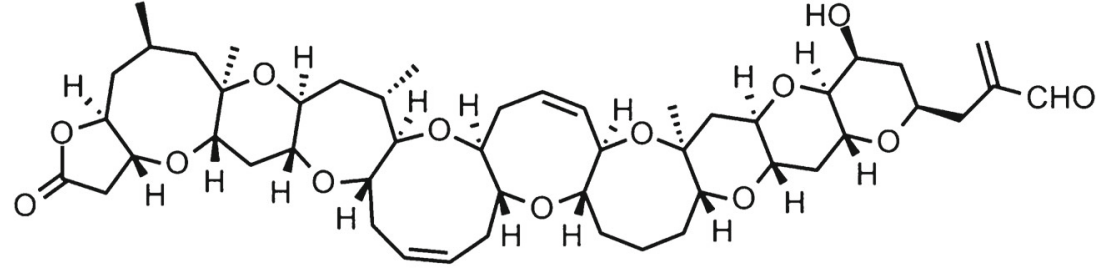

(10) Brevetoxins demonstrated an antialgal activity (Fig. 4). The latter may be based on the fact that the production of antialgal metabolites would be an ecological advantage in a specific niche and/or space. Furthermore, organisms like mollusks and crustaceans not only compete with benthic microalgae for space, but are also important microalgal consumers, with the ability to affect microalgal populations.

\section{A case study: antifouling compounds from Southeast Asia}

Southeast Asia has an outstanding species richness and endemism. It has an extensive coastline (e.g., Indonesia, $81.000 \mathrm{~km}$; Vietnam, $3.260 \mathrm{~km}$ ) with many islands and rivers flowing into the extended and large continental shelf (Aungtonya and Liao 2002; Gerung et al. 2006; Soe-Htun et al. 2009; Phang et al. 2015). This produces a diverse variety of ecosystems, ranging from extensive lagoons, estuaries, and mangroves, to rocky shores and coral reefs, which provide suitable habitats for luxuriant algal growth (Nguyen et al. 2013). In fact, the triangle formed by the Malay Peninsula, The Philippines, plus New Guinea ("The Coral Triangle") is recognized as a global biodiversity hotspot where most tropical marine groups have their greatest diversity of species (Todd et al. 2010; Selig et al. 2014). Researchers have noticed that a high diversity of species may be translated in a higher diversity of secondary metabolites. But not only that, those species may harbor silent gene clusters coding the production of "new" metabolites, which may be expressed under different environmental conditions (Bode et al. 2002; Brakhage and Schroeckh 2011). Thus, biogeography may multiply this number and even enhance bioactivity of such metabolites.

The exact number of macro- and micro-algal species for Southeast Asia is still unknown and there are many species yet to be discovered (Kawaguchi and Hayashizaki 2011).

Table 2 Antifouling compounds and extracts from dinoflagellates and diatoms

\begin{tabular}{|c|c|c|c|c|}
\hline Source & Biogenic compound(s)/ type of extract & Bioactivity & Origin & Reference \\
\hline Alexandrium tamarense $e^{\mathrm{DF}}$ & Lipidic extracts & AA & Scotland & Ma et al. 2011 \\
\hline Amphora cf. capitellata ${ }^{\mathrm{DI}}$ & Ethanol extract & $\mathrm{AF}$ & Turkey & Montalvaõ et al. 2016 \\
\hline Isochrysis galbana ${ }^{\mathrm{HA}}$ & Fatty acids & $\mathrm{AB}$ & Isle of Man & Molina-Cárdenas et al. 2014 \\
\hline Karenia brevis $^{\mathrm{DF}}$ & Culture extracts, 6 unidentified compounds & AA & USA & Poulson et al. 2010 \\
\hline Karenia brevis ${ }^{\mathrm{DF}}$ & Diverse metabolites & AA & USA & Prince et al. 2010 \\
\hline Karenia brevis ${ }^{\mathrm{DF}}$ & Culture extracts, unidentified compounds & AA & USA & Poulson-Ellestad et al. 2014 \\
\hline Karenia brevis $^{\mathrm{DF}}$ & Culture extracts, brevetoxins ${ }^{10}$ & AMF, TX & USA & Rolton et al. 2014 \\
\hline Lingulodinium polyedrum $^{\mathrm{DF}}$ & Diverse extracts & $\mathrm{AB}$ & Mexico & Quijano-Scheggia 2016 \\
\hline Nitzschia communis $^{\mathrm{DI}}$ & Ethanol extract & $\mathrm{AB}$ & Turkey & Montalvaõ et al. 2016 \\
\hline 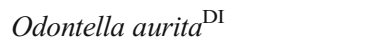 & Ethanol extract & $\mathrm{AB}$ & India & Hemalatha et al. 2016 \\
\hline Ostreopsis cf. ovata ${ }^{\mathrm{DF}}$ & Culture extracts & AMF, TX & Italy & Caroppo and Pagliara 2011 \\
\hline Ostreopsis cf. ovata ${ }^{\mathrm{DF}}$ & Palytoxin-like compounds & AMF, TX & Italy & Gorbi et al. 2012 \\
\hline Phaeodactylum tricornutum ${ }^{\mathrm{DI}}$ & Culture extracts & $\mathrm{AA}$ & China & Cai et al. 2014 \\
\hline Prorocentrum donghaiense ${ }^{\mathrm{DF}}$ & Culture extracts & AA & China & Cai et al. 2014 \\
\hline Protoceratium reticulatum ${ }^{\mathrm{DF}}$ & Culture extracts & AA & Greenland & Sala-Pérez et al. 2016 \\
\hline Skeletonema marinoi $^{\mathrm{DI}}$ & Acetonic extracts & $\mathrm{AB}$ & Italy & Lauritano et al. 2016 \\
\hline Thalassiosira rotula $^{\mathrm{DI}}$ & Diverse extracts & $\mathrm{AB}$ & Australia & Qin et al. 2013 \\
\hline
\end{tabular}

The bioactivities are the following: antibacterial activity (AB), antifungal (AF), anti-macroalgal (AM), anti-microalgal including diatoms and cyanobacteria (AA), anti-macrofouling including mollusks (AMF), quorum sensing disruptor (QSD), anti-biofilm (ABF), and toxins (TX). Also the algae groups: diatoms (DI), dinoflagellates (DF), and haptophytes (HA). $10=$ compound listed in Fig. 3 
Fig. 4 Bioactivity of metabolites or extracts fractions from a total of six species of dinoflagellates, five species of diatoms and one haptophyte, active against marine relevant species during the period 2010-2016. Antibacterial activity $(\mathrm{AB})$, antifungal (AF), antimicroalgal including diatoms and cyanobacteria (AA), antimacrofouling including mollusks and crustacean (AMF), quorum sensing disruptor (QSD), toxins (TX), and anti-biofilm (ABF)
Marine microalgae spp.

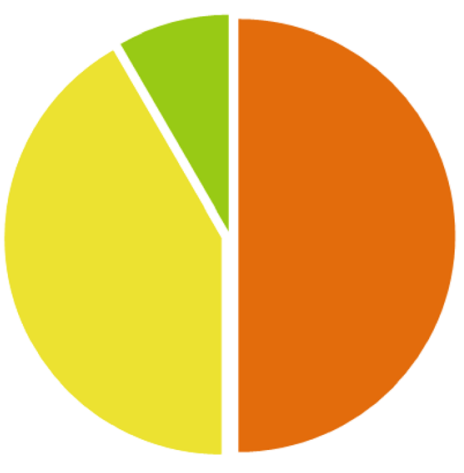

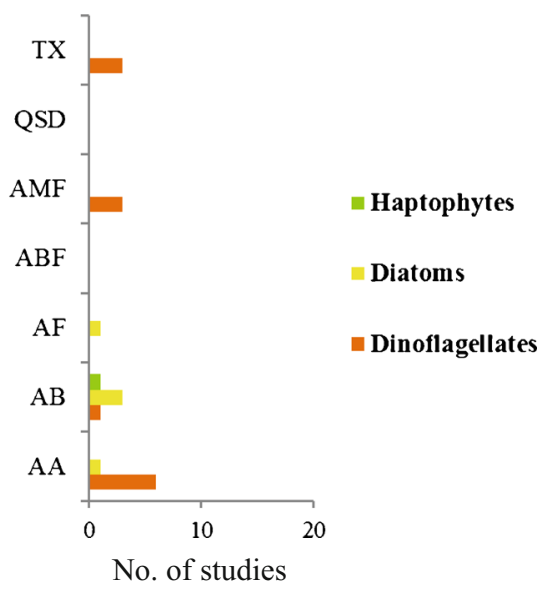

Research has mostly focused on economic resources, as several macroalgae are important economic resources in Southeast Asia (S.E.A.). Thus, the existing coverage of species is conspicuous by the omission of small groups (Wafar et al. 2011), or other "less important" economic species, and therefore, we understand little of their distributions and potential uses (Webb et al. 2010). Given the unlocked potential of algal compounds from S.E.A, in this review, we have highlighted the importance of exploring this area with more depth.

\section{Algal compounds in general from S.E.A}

If we compare the collection effort globally of all type of organisms, the S.E.A region has been well explored and reporting of compounds from these regions has been rapidly accelerating since 1990 (Blunt et al. 2016). According to Blunt et al. (2016), maritime Southeast Asia (and Papua New Guinea) has produced in 50 years 1340 compounds as reported in 502 publications, plus the mainland of Southeast Asia (including East Malaysia) has produced 457 compounds in 173 publications. However, considering the information in the excellent reviews of new marine natural products published by Blunt et al. (2011, 2012, 2013, 2014, 2015, 2016), between the years 2008 to 2014, the contribution of compounds isolated from marine algae species growing in S.E.A is limited to only 29 compounds, from which only 23 are newly described for science (Table 3 ), when compared to the compounds described from algae collected worldwide. It is also interesting to note that the investigations were mostly limited to red algae of the genus Laurencia (Table 4). When we compare the total amount of new natural compounds reported from marine algae worldwide, the yield of natural compounds from marine algae reported from Southeast Asia is not significant (Fig. 5), contradicting the great diversity of the area.

\section{Antifouling compounds from S.E.A}

Although, studies looking at the antifouling activity of algae (micro and macro) are limited in S.E.A. compared to European and North American waters (Fig. 5), nevertheless studies over the last decade have shown promising antifouling activities from Southeast Asian algae. Majority of the studies from Southeast Asian waters have been largely focused on marine macroalgae, and antifouling activity was examined based on crude extract assays (e.g. Bhadury and Wright 2004 and references within; Sidharthan et al. 2004; Qian et al. 2010 and references within; Satheesh et al. 2016 and references within). Identified compounds so far from Southeast Asia with AF activity are provided in Fig. 6. An integrative approach involving identification of secondary metabolites from the crude extracts has been far less studied compared to information available from other geographical origins. This reflects the need to undertake approaches involving GC-MS and NMR for identification of potential potent antifouling secondary metabolites. While, Southeast Asia harbors high biodiversity including rich marine microalgae and macroalgal diversity, their potential for antifouling activity in an ecological context is yet to be effectively explored.

\section{Linking genes to biofilm formation}

Among the early colonizers, diatoms play a significant role in biofilm development and are able to colonize on even most fouling-resistant surfaces (Molino and Wetherbee 2008). Currently, our understanding of the role of genes during bacteria-diatom interaction as part of biofilm formation is relatively well understood (e.g., Buhmann et al. 2012 and references within). However, limited knowledge exists in terms of the genes that are exclusively found in marine diatoms and their link to marine biofilm formation. The recent availability of phytoplankton genome sequence data, in particular diatom genomes, has resulted in improved 
Table 3 Detail of the yearly new identified natural compounds isolated from different marine algae groups (data based on Blunt et al. 2016). The contribution of compounds isolated from species growing in Southeast Asia (S.E.A) is specified

\begin{tabular}{|c|c|c|c|c|c|c|c|c|c|c|c|c|c|c|}
\hline \multirow[b]{2}{*}{ Organisms } & \multicolumn{14}{|c|}{ New identified compounds } \\
\hline & $\begin{array}{l}2008 \\
\text { total }\end{array}$ & $\begin{array}{l}2008 \\
\text { SEA }\end{array}$ & $\begin{array}{l}2009 \\
\text { total }\end{array}$ & $\begin{array}{l}2009 \\
\text { SEA }\end{array}$ & $\begin{array}{l}2010 \\
\text { total }\end{array}$ & $\begin{array}{l}2010 \\
\text { SEA }\end{array}$ & $\begin{array}{l}2011 \\
\text { total }\end{array}$ & $\begin{array}{l}2011 \\
\text { SEA }\end{array}$ & $\begin{array}{l}2012 \\
\text { total }\end{array}$ & $\begin{array}{l}2012 \\
\text { SEA }\end{array}$ & $\begin{array}{l}2013 \\
\text { total }\end{array}$ & $\begin{array}{l}2013 \\
\text { SEA }\end{array}$ & $\begin{array}{l}2014 \\
\quad \text { total }\end{array}$ & $\begin{array}{l}2014 \\
\text { SEA }\end{array}$ \\
\hline Dinoflagellates & 8 & 0 & 12 & 0 & 17 & 0 & 2 & 0 & 2 & 0 & 9 & 0 & 19 & 0 \\
\hline $\begin{array}{l}\text { Diatoms, other } \\
\text { microalgae }\end{array}$ & 1 & 0 & 0 & 0 & 0 & 0 & 3 & 0 & 0 & 0 & 4 & 0 & 0 & 0 \\
\hline Chlorophyta & 4 & 0 & 6 & 0 & 8 & 0 & 3 & 0 & 2 & 0 & 5 & 0 & 13 & 0 \\
\hline Phaeophyceae & 45 & 0 & 25 & 0 & 10 & 0 & 25 & 0 & 32 & 0 & 17 & 0 & 17 & 0 \\
\hline Rhodophyta & 24 & 3 & 49 & 0 & 47 & 7 & 41 & 1 & 45 & 1 & 9 & 0 & 41 & 1 \\
\hline
\end{tabular}

understanding of mechanisms that control their growth and distribution in the marine environment (e.g., Armbrust et al. 2004; Bowler et al. 2008). Thus, the rapidly available diatom genome datasets can help in understanding the role of biosynthetic pathways towards production and regulation of extracellular polymeric substances (EPS) during the process of biofouling.

From the cellular viewpoint, the adhesive components of EPS are involved in diatom cell-substratum adhesion, in addition to motility. EPS molecules are secreted from frustules through pores in the girdle bands and valves. The carbohydrate components of the EPS have been characterized in various benthic diatoms (e.g., Chiovitti et al. 2008; Abdullahi et al. 2006). It is already well known that EPS secretion in diatoms depends on numerous factors including nutrient availability, daily fluctuations, irradiance, and even metal toxicity (Staats et al. 1999; Ai et al. 2015). This is particularly significant since EPSs can be a food source for heterotrophic organisms and affect the detachment of biofilms (e.g., De Brouwer and Stal 2002; Bellinger et al. 2005). For example, nitrogen and phosphate limitations affect production rate of EPSs including chemical composition in various diatoms (Magaletti et al. 2014; Ai et al. 2015). Mass spectrometry of EPSs of
Thalassiosira pseudonana shows that degree of polymerization and distribution of EPSs can vary in response to nutrient depletion and different nutrient sources (Ai et al. 2015). Proteins and glycoproteins have been studied by chemical methods and by atomic force microscopy (Lind et al. 1997; Wustman et al. 1997; Dugdale et al. 2006; Chiovitti et al. 2008). It has been shown that the adhesive molecules appear to be highly glycosylated with novel glycans that are highly sulphated (Chiovitti et al. 2003, 2008).

In a recent study, from the available genome dataset of the pennate diatom Phaeodactylum tricornutum, bioinformatic analysis was undertaken to identify putative diatom cell substratum adhesion molecules (PDC) (Willis et al. 2014). In total, 37 PDCs were identified from the $P$. tricornutum genome, of which some showed similarities to genes found in a diverse range of organisms, including metazoans, plants, and prokaryotes, as well as algae, encoding components of the extracellular matrix (ECM) or cell adhesion complexes (Yamada and Geiger 1997; Zhao and Waite 2006). It has been found that genes that code for PDCs have characterizing features that are common to a set of cell adhesion molecule (CAM) genes (Willis et al. 2014). Indeed, using bioinformatic approach, we detected the presence of CAM genes across

Table 4 Natural compounds isolated from different marine algae groups from Southeast Asia (data based on Blunt et al. 2016). The geographical origin and bioactivity of compounds are specified

\begin{tabular}{|c|c|c|c|c|}
\hline Taxa & Compound & Bioactivity & Origin & Reference \\
\hline Gracilaria edulis $^{\mathrm{RH}}$ & Levuglandin $\mathrm{D}_{2}{ }^{\mathrm{n}}$ & - & The Philippines & Kanai et al. 2011 \\
\hline Laurencia nangii $^{\mathrm{RH}}$ & $\begin{array}{l}\text { Dihydroitomanallene } \mathrm{B}^{\mathrm{n}} \\
\text { pannosallene }{ }^{11} \\
\text { itomanallene } \mathrm{B}^{12}\end{array}$ & - & Malaysia & Kamada and Vairappan 2012 \\
\hline Laurencia snackeyi ${ }^{\mathrm{RH}}$ & $5 \beta$-Hydroxypalisadin $\mathrm{B}^{\mathrm{n}, 13}$ & - & Malaysia & Wijesinghe et al. 2014 \\
\hline Laurencia sp. ${ }^{\mathrm{RH}}$ & Laurefurenyne A- $\mathrm{F}^{\mathrm{n}, 14,15,16}$ & cytotoxic & The Philippines & Abdel-Mageed et al. 2010 \\
\hline Laurencia sp. ${ }^{\mathrm{RH}}$ & $\begin{array}{l}\text { Tiomanene }^{\mathrm{n}} \\
\text { acetylmajapolene A-B }{ }^{\mathrm{n}, 17}\end{array}$ & - & Malaysia & Vairappan et al. 2008 \\
\hline
\end{tabular}

$n$ new compounds

RH rhodophyta

${ }^{11-17}$ Compounds listed in Fig. 6 
Fig. 5 Studies conducted between January 2010 and June 2016 based on geographical locations. $\%$ by zone $=$ America $32 \%$, Europe $34 \%$, Africa $6 \%$, Oceania $2 \%$, Asia $23 \%$, S.E.A. $4 \%$ (of the $23 \%$ of Asia)

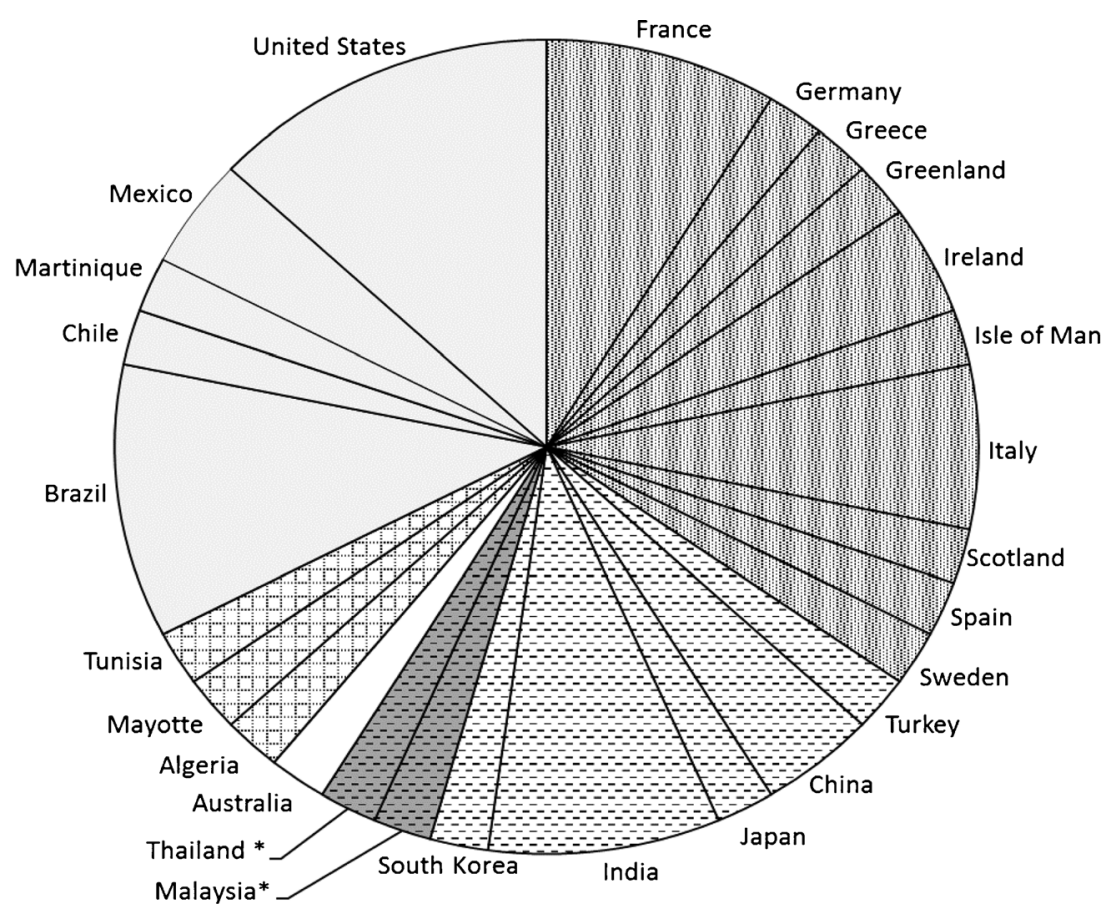

sequenced marine micro- and macroalgal genomes (Fig. 7). As evident from Fig. 4, these amino acid sequences representing CAM are conserved across different marine algae and thus may also indicate the possible existence of putative PDCs in published marine algal genomes. Willis et al. (2014) reported that some of the PDCs were diatom specific and encoded unclear functions. These putative genes indicate that there is likely a diverse range of molecules that diatoms use for cell substratum adhesion and therefore these genes potentially may play key role in biofouling. Seven of these PDC have been characterized in vivo, by generation of transgenic diatom lines over-expressing genes encoding Cterminal yellow fluorescent protein (YFP) fusion proteins, and showed that these candidate proteins are involved in diatom cell adhesion. Based on the analysis of the T. pseudonana genome, several putative cell adhesion molecules have been identified using bioinformatics approach.

From the available transcriptome data of the model adhesion diatom, Amphora coffeaeformis, five proteins have been identified that exhibit unique amino acid sequences resembling the amino acid composition of the tyrosine-rich adhesion proteins from mussel footpads (Buhmann et al. 2014). Buhmann et al. (2014) looked into the function of one of these proteins, AC3362 by undertaking genetic transformation of $A$. coffeaeformis. They found that AC3362 plays a role in biosynthesis and or structural stability of the cell wall of this pennate diatom. The findings of AC3362 protein is particularly significant since in many mussel foot proteins, tyrosine<smiles>CCC(C)C1CC=CCC2O[C@H](C=C=CBr)CC2O1</smiles>

(11) Pannosallene<smiles>CC/C=C/C/C=C\C[C@H]1OC(C#CBr)C[C@H]1OC(=O)O</smiles>

(12) Itomanallene B<smiles>C#CCCC1OCC(CC)OC(CC)CC1O</smiles>

\section{(16) Laurefurenyne F}

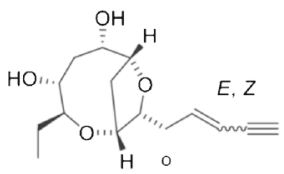

(15) Laurefurenyne C<smiles>[2H][C@@H]1CC[C@@]2(C)O[C@@H]([B])C(C)=C[C@H](C)[C@]2(C)C1(C)C</smiles>

(13) $5 \beta$-hydroxypalisadin $B$ $\mathrm{R}=\mathrm{OH}$

(14) LaurefurenyneA-B ( $Z$ and $E$ denotes isomer)

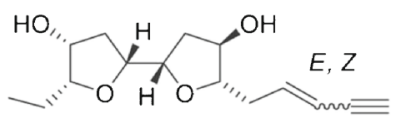<smiles>CC(C)[C@]1(O)CC[C@]2(C)[C@@H](C)CC[C@H](C)[C@]2(C)C1</smiles>

(17) Acetylmajapolene A

Fig. 6 Antifouling compounds isolated from Southeast Asian macroalgae 
GuillardiathetaCCMP2712 Gracilariopsislemaneiformis

Aureococcusanophagef ferens

TpseudonanaCCMP1335

ptricornutumCCAP1055

\section{1}

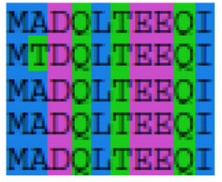

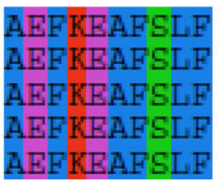

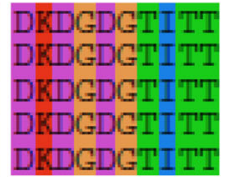

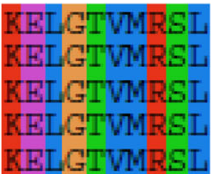

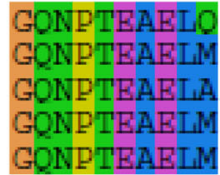

GuillardiathetaCCMP2 712 Gracilariopsislemaneiformis Aureococcusanophagef ferens TpseudonanaCCMP1335 ptricornutumCCAP1055
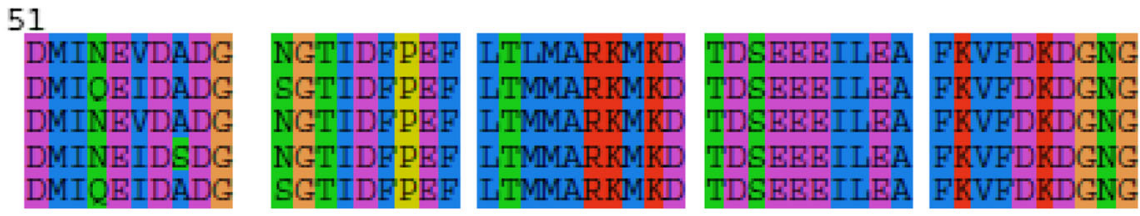

101

GuillardiathetaCCMP2 712 Gracilariopsislemaneiformis Aureococcusanophagefferens TpseudonanaCCMP1335 PtricornutumCCAP1055
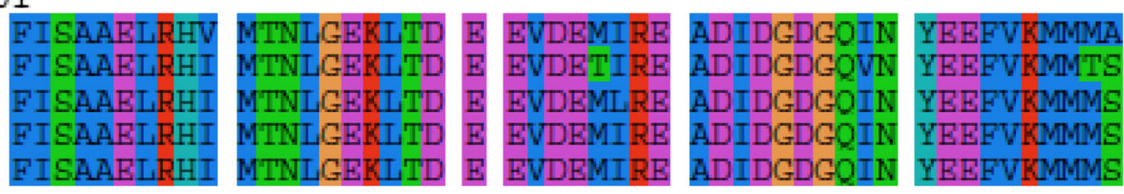

GuillardiathetaCCMP2 712 Gracilariopsislemaneiformis Aureococcusanophagef ferens TpseudonanaCCMP1335 ptricornutumCCAP1055

151

Fig. 7 Amino acid sequence alignment of CAM gene from Thalassiosira pseudonana CCMP1335 (Acc No. XM_002295719), Aureococcus anophagefferens (Acc No XP_009033803), Phaeodactylum

tricornutum CCAP1055 (Acc No. XP_002185049), Guillardia theta CCMP2712 (Acc No. XP_005836584) and Gracilariopsis lemaneiformis (Acc No. AKG55580) showing highly conserved regions

residues have been post-translationally hydroxylated to 3,4dihydroxyphenyl-L-alanine (Dopa) (Waite and Tanzer 1981). The presence of Dopa seems to play an important role in both structural integrities of the filaments and underwater adhesion to surfaces by forming covalent cross-links and coordination bonds with metal ions, as well as by forming hydrogen bonds with the surface. The AC3362 protein identified in A. coffeaeformis resembles the cingulins from the diatom T. pseudonana, which are also rich in tyrosine residues (Kröger and Poulsen 2008; Sumper and Brunner 2008). It will be therefore important to investigate using bioinformatics and experimental approaches the existence of similar homologs of this protein in other marine diatoms which are known to contribute to biofilm formation.

While the importance of EPS in biofilm formation is well known, other metabolic pathways are increasingly important in controlling diatom biofilm formation (e.g., Thompson et al. 2008). For example, it has been shown that a novel gene (PtNOA) linked to nitric oxide production (NO) along with its role in ribosome biogenesis and sporulation has been identified in P. tricornutum (Vardi et al. 2008). When this gene is over-expressed in transgenic diatoms, higher NO production is displayed and ultimately there is reduced ability to adhere to surfaces which is important in biofilm formation (Vardi et al. 2008). It is interesting to note that NOA-like sequences have been encountered in other marine diatoms and thus the role of this gene needs further investigation from the perspective of biofilm formation. Given that we are now starting to

understand specific role of genes and proteins of microalgal origin in marine biofilm, the above information could help us to delineate basis of physiological complexity within a single microalgal species biofilm. Such morphological, physiological, and genetic basis of complexity is already under investigation with respect to prokaryotic single species biofilms (e.g., Archaea: Brazelton et al. 2011; Bacteria: Seth et al. 2012). Moreover, the identification of genes that implicitly regulates microalgal biofilm formation could form the basis for inbiofilm expression technology for understanding other microalgal-mediated biofilms as the above approach has been undertaken in case of bacterial biofilms (e.g., Finelli et al. 2003). Since diatoms play a crucial role in biofilm formation, it is essential therefore to undertake further identification of such genes, develop knockouts for disruption of biofilm, develop robust screening methodologies based on genetic data to identify stages of biofim, and ultimately strategize manipulation methods that could be used to biofouling under control from commercial viewpoint.

\section{Industrial scale-up of compounds production}

Detection of antifouling potential from natural resources like macroalgae is not enough to meet the actual global demand. Thus, industrial scale up of novel antifouling compounds is a prerequisite. However, there are important limitations to industrially scale-up the production of antifouling metabolites from macroalgae. In general, extracting sufficient amounts of 
these metabolites may be extremely difficult due to limited quantity of the producer organism, the small amount of a specific compound within the target organism, or the variability of the concentration of these metabolites in response to biotic and abiotic factors. In consequence, the extraction of natural beds of seaweeds is not only ecologically destructive but it can also be unstable over time (Proksch et al. 2003; Pereira and Costa-Lotufo 2012), although large-scale extraction from drift algae may be possible (Siless et al. 2017). Given the limitations encountered with macroalgae, photosynthetic microorganisms are attracting considerable interest towards a sustainable production of natural products. This is due to their relatively high photosynthetic conversion efficiency, novel and diverse metabolic capabilities, faster growth rates, ability to thrive in diverse ecosystems, and ability to store or secrete energy-rich hydrocarbons (Radakovits et al. 2010). In theory, by using (cheap) sunlight and carbon dioxide (which is normally a waste), microalgae can produce high value metabolites of economic importance (such as antifouling metabolites). The potential productivity can be tenfold greater than that of agricultural crops and it can take place on non-arable land (Wijffels 2007). Thus, all these factors taken together makes them economically attractive and more environmentally friendly source of antifouling compounds.

Commercial large-scale culture of microalgae started in the early 1960s with Chlorella, and in a short period, the associated biotechnology industry has grown and diversified significantly (Spolaore et al. 2006; Borowitzka 2013b). These microorganisms are important sources of commercially produced highvalue chemicals including carotenoids, long-chain polyunsaturated fatty acids, and phycobilins (Borowitzka 2013a). Markets of microalgae products already exist and are growing, but the growth of the markets is limited by the production technology used and cost-price of products, mostly limiting the commercial production to high-value products (Wijffels 2007). Among the main limitations for a successful algal industrial cultivation is the development of easy to use/low cost large operations systems, which also combine a sustainable use of water, temperature, light, nutrients, and gas resources, with limited microbial contamination, necessary to reduce the cost of production while maintaining and improving product quality (Courchesne et al. 2009; Ugoala et al. 2012).

Strain selection is also an important factor. So far, cultivation of microalgae has been limited to wild type strains of different species and bioprospecting has been used to isolate new strains with interesting and optimally combined properties (Hlavová et al. 2015). Microalgae are an extremely diverse group of organisms, which has not yet been fully explored in terms of diversity (Borowitzka 2013a). However, researchers are starting to believe that the most cost-effective way for industrial production lies in further improvements of current strains (Hlavová et al. 2015). It is believed that metabolic engineering is the way forward in case of large scale production of promising marine algal bioactive metabolites with antifouling potential (Bhadury and Wright 2004). For example, the possibility of using metabolic engineering approach to scale-up production of poly-unsaturated fatty acids has been explored in marine microalgae with some success (e.g., Courchesne et al. 2009, Khozin-Goldberg and Cohen 2011; see review by Mühlroth et al. 2013).

Metabolic engineering tools have been also used for overproduction of astaxanthin in microalgae by looking into the over-expression of PSY and CrtR-b genes in Haematococcus pluvialis (Chlorophyceae) (Li et al. 2008). Given that several marine algal genomes have been sequenced, such large-scale dataset has been also integrated as part of metabolic engineering tools. In the model marine diatom, P. tricornutum, intervention of metabolic engineering has enhanced accumulation of omega-3 long chain polyunsaturated fatty acids through generation of transgenic strains (Hamilton et al. 2014). Very recently, integration of flux balance analysis (FBA) and in silico proteomics has also shown promising results in terms of metabolic engineering application for sustainable microalgal energy development (e.g., Banerjee et al. 2016).

As mentioned, the industrial scale up of microalgae still faces several technological limitations which have to be considered for competing with commodities such as cuprous oxide, but we consider it important to explore the possibility of producing effective and more environmental friendly products. There is huge potential for application of metabolic engineering techniques for ultimate industrial scale-up of antifouling metabolites from marine microalgal origin. In theory, it offers not only the possibility to overcome "secondary production bottlenecks" but also to allow us to direct the production of secondary metabolites, or of important substrates for later synthesis of such antifouling compounds. Since establishment of transgenic microalgal strains has been (relatively) easy, a large production of metabolites with antifouling applications possibly can be achieved. This is supported by the increasing availability of genome level data generated from "omics"-based approaches which can be used as part of RNAi and riboswitch engineering approaches and may lead to enhanced production of antifouling metabolites. At the same time, it can be synchronized with rational biochemical engineering design for large-scale production of marine algal antifouling metabolites using photobioreactor technology. Given that there has been significant technological development in the field of metabolic engineering, one could expect that in coming years, this approach could prove to be useful for development of antifouling paints. However, the genetic improvement of algal strains is a current (moral and practical) challenge till now. Modified strains could overproduce traditional or newly discovered algal compounds and also serve to express specific genes that cannot be expressed into other organisms (Spolaore et al. 2006) and, therefore, produce different products under specific cultivation 
conditions. Radakovits et al. (2010) mentioned that more than 30 different strains of microalgae have been transformed successfully, but the use of transgenic microalgae for commercial applications has not been reported yet.

As new species are discovered and sequenced, and new tools become available for genetic manipulation, the rich diversity of microalgae can be exploited for new applications (Ruffing 2011). The possibility of producing a large amount of biomass in more environmentally friendly conditions offers higher chances for a successful industrial scale-up of the process. It is likely that such advances can be extended to industrially relevant microorganisms in the field of antifouling compounds.

\section{Conclusions}

Given the evidence that has built up in the last few years reporting antifouling compounds extracted and isolated from marine algae - undoubtedly they continue to be a potential source for novel antifouling compounds with antibacterial, antibiofilm, antialgal, and anti-macrofouling properties. However, significant progress in terms of (a) fouling control in an environmentally friendly way and (b) successful exploitation of the reported active compounds is yet to be achieved and there is possibly still some way to go for full commercial use of such compounds. While we should still continue looking for such compounds in general and also exploit the untapped potential of S.E.A out of academic interests if not bioprospecting, we highlight the importance of (a) linking up biofilm formation with the diatom genes involved as identification of such genes could form the basis of future biofilm knockout mechanisms and (b) the need to put together screening, genomic, and metabolic engineering studies under one roof for successful interdisciplinary exploitation of such rich biodiversity of marine algal compounds.

Acknowledgements P. Bhadury acknowledges ARF grant of IISER Kolkata.

Open Access This article is distributed under the terms of the Creative Commons Attribution 4.0 International License (http:// creativecommons.org/licenses/by/4.0/), which permits use, duplication, adaptation, distribution and reproduction in any medium or format, as long as you give appropriate credit to the original author(s) and the source, provide a link to the Creative Commons license, and indicate if changes were made.

\section{References}

Abdel-Mageed WM, Ebel R, Valeriote FA, Jaspars M (2010) Laurefurenynes A-F, new cyclic ether acetogenins from a marine red alga, Laurencia sp. Tetrahedron 66:2855-2862

Abdullahi AS, Underwood GJC, Gretz MR (2006) Extracellular matrix assembly in diatoms (Bacillariophyceae). V. Environmental effects on polysaccharide synthesis in the model diatom, Phaeodactylum tricornutum. J Phycol 42:363-378

Abida H, Ruchaud S, Rios L, Humeau A, Probert I, De Vargas C, Bach S, Bowler C (2013) Bioprospecting marine plankton. Mar Drugs 11: 4594-4611

Águila-Ramírez RN, Arenas-González A, Hernández-Guerrero CJ, González-Acosta B, Borges-Souza JM, Verón B, Pope J, Hellio C (2012) Antimicrobial and antifouling activities achieved by extracts of seaweeds from gulf of California, Mexico. Hidrobiológica 22(1): $8-15$

Ai X-X, Liang J-R, Gao Y-H, Lo SC-L, Lee FW-F, Chen C-P, Luo C-S, Du C (2015) MALDI-TOF MS analysis of the extracellular polysaccharides released by the diatom Thalassiosira pseudonana under various nutrient conditions. J Appl Phycol 27:673-684

Armbrust EV, Berges JA, Bowler C, Green BR, Martinez D, Putnam NH, Zhou SG, Allen AE, Apt KE, Bechner M et al (2004) The genome of the diatom Thalassiosira pseudonana: ecology, evolution, and metabolism. Science 306:79-86

Aungtonya C, Liao LM (2002) Marine flora (algae and seagrasses) in the reference collection of the Phuket marine biological center, Thailand. Phuket Mar Biol Cent. Res Bull 64:65-80

Bagwell CE, Abernathy A, Barnwell R, Milliken CE, Noble PA, Dale T, Beauchesne KR, Moeller PDR (2016) Discovery of bioactive metabolites in biofuel microalgae that offer protection against predatory bacteria. Front Microbiol 7:516

Banerjee C, Dubey KK, Shukla P (2016) Metabolic engineering of microalgal based biofuel production: Prospects and challenges. Front Microbiol 7:432

Batista D, Carvalho A, Costa R, Coutinho R, Dobretsov S (2014) Extracts of macroalgae from the Brazilian coast inhibit bacterial quorum sensing. Bot Mar 57:441-447

Bellas J (2006) Comparative toxicity of alternative antifouling biocides on embryos and larvae of marine invertebrates. Sci Total Environ 367:573-585

Bellinger BJ, Abdullahi AS, Gretz MR, Underwood GJC (2005) Biofilm polymers: relationship between carbohydrate biopolymers from estuarine mudflats and unialgal cultures of benthic diatoms. Aquat Microb Ecol 38:169-180

Blunt JW, Copp BR, Hu WP, Munro MH, Northcote PT, Prinsep MR (2009) Marine natural products. Nat Prod Rep 26(2):170-244

Bhadury P, Wright PC (2004) Exploitation of marine algae: biogenic compounds for potential antifouling applications. Planta 219:561578

Blunt JW, Copp BR, Munro MHG, Northcote PT, Prinsep MR (2011) Marine natural products. Nat Prod Rep 28:196-268

Blunt JW, Copp BR, Keyzers RA, Munro MHG, Prinsep MR (2012) Marine natural products. Nat Prod Rep 29:144-222

Blunt JW, Copp BR, Keyzers RA, Munro MHG, Prinsep MR (2013) Marine natural products. Nat Prod Rep 30:237-323

Blunt JW, Copp BR, Keyzers RA, Munro MHG, Prinsep MR (2014) Marine natural products. Nat Prod Rep 31:160-258

Blunt JW, Copp BR, Keyzers RA, Munro MHG, Prinsep MR (2015) Marine natural products. Nat Prod Rep 32:116-211

Blunt JW, Copp BR, Keyzers RA, Munro MHG, Prinsep MR (2016) Marine natural products. Nat Prod Rep 33:382-431

Bode HB, Bette B, Höfs R, Zeek A (2002) Big effects from small changes: possible ways to explore nature's chemical diversity. Chem Bio Chem 3:619-627

Borowitzka MA (2013a) High-value products from microalgae - their development and commercialisation. J Appl Phycol 25:743-756

Borowitzka MA (2013b) Energy from microalgae: a short history. In: Borowitzka MA, Moheimani NR (eds) Algae for biofuels and energy. Springer, Dordrecht, pp 1-15

Borowitzka MA (2016) Chemically-mediated interactions in microalgae. In: Borowitzka MA, Beardall J, Raven JA (eds) The physiology of microalgae. Springer, Dordrecht, pp 321-357 
Bowler C, Allen AE, Badger JH, Grimwood J, Jabbari K, Kuo A, Maheswari U, Martens C, Maumus F, Otillar RP et al (2008) The Phaeodactylum genome reveals the evolutionary history of diatom genomes. Nature 456:239-244

Bragadeeswaran S, Prabhu K, Thangaraj K, Ganesan RS (2011a) Biological activity of seaweed extracts from Cladophora clavuligera (Kutzing, 1843) and Sargassum wightii (Greville, 1995) against marine fouling bacteria. Ind J Geo-Mar Sci 40:398402

Bragadeeswaran S, Thangaraj S, Prabhu K, Rani S (2011b) Antifouling activity by sea anemone (Heteractis magnifica and H. aurora) extracts against marine biofilm bacteria. Lat Am J Aquat Res 39:385389

Brakhage AA, Schroeckh V (2011) Fungal secondary metabolites - strategies to activate silent gene clusters. Fung Genet Biol 48:15-22

Brazelton WJ, Mehta MP, Kelley DS, Baross JA (2011) Physiological differentiation within a single-species biofilm fuelled by serpentinization. mBio 2:4e00127-4e00111

Buhmann M, Kroth PG, Schelheck D (2012) Photoautotrophic- heterotrophic biofilm communities: a laboratory incubator designed for growing axenic diatoms and bacteria in defined mixed-species biofilms. Environ Microb Rep 4:133-140

Buhmann MT, Poulsen N, Klemm J, Kennedy MR, Sherrill CD, Kröger N (2014) A tyrosine-rich cell surface protein in the diatom Amphora coffeaeformis identified through transcriptome analysis and genetic transformation. PLoS One 9:e110369

Cai Z, Zhu H, Duan S (2014) Allelopathic interactions between the redtide causative dinoflagellate Prorocentrum donghaiense and the diatom Phaeodactylum tricornutum. Oceanologia 56:639-650

Callow JA, Callow ME (2011) Trends in the development of environmentally friendly fouling-resistant marine coatings. Nature Comm 2:244

Caroppo C, Pagliara P (2011) Effects of Ostreopsis Cfr. ovata (Dinophyceae) toxicity on Paracentrotus lividus development. Biol Mar Med 18:74-76

Carvalho AP, Batista D, Dobretsov S, Coutinho R (2017) Extracts of seaweeds as potential inhibitors of quorum sensing and bacterial growth. J Appl Phycol 29:789-797

Cen-Pacheco F, Santiago-Benítez AJ, García C, Álvarez-Méndez SJ, Martín-Rodríguez AJ, Norte M, Martín VS, Gavín JA, Fernández JJ, Daranas AH (2015) Oxasqualenoids from Laurencia viridis: combined spectroscopic-computational analysis and antifouling potential. J Nat Prod 78:712-721

Chambers LD, Stokes KR, Walsh FC, Wood RJK (2006) Modern approaches to marine antifouling coatings. Surf Coat Technol 201: 3642-3652

Chambers LD, Hellio C, Stokes KR, Dennington SP, Goodes LR, Wood RJK, Walsh FC (2011) Investigation of Chondrus crispus as a potential source of new antifouling agents. Int Biodeter Biodegr 65: 939-946

Chapman J, Hellio C, Sullivan T, Brown R, Russell S, Kiterringham E, Nor L, Regan F (2014) Bioinspired synthetic macroalgae: examples from nature for antifouling applications. Int Biodeter Biodegr 86:613

Chiovitti A, Bacic A, Burke J, Wetherbee R (2003) Heterogeneous xylose-rich glycans are associated with extracellular glycoproteins from the biofouling diatom Craspedostauros ausstralis (Bacillariophyceae). Eur J Phycol 38:351-360

Chiovitti A, Heraud P, Dugdale TM, Hodson OM, Curtain RCA, Dagastine RR, Wood BR, Wetherbee R (2008) Divalent cations stabilize the aggregation of sulfated glycoproteins in the adhesive nanofibers of the biofouling diatom Toxarium undulatum. Soft Matter 4:811-820

Cho J (2013) Antifouling chromanols isolated from brown alga Sargassum horneri. J Appl Phycol 25:299-309
Clément A, Lincoqueo L, Saldivia M, Brito CG, Muñoz F, Fernández C, Pérez F, Maluje CP, Correa N, Mondaca V, Contreras G (2016) Exceptional summer conditions and HABs of Pseudochattonella in southern Chile create record impacts on salmon farms. Harmful Algae News 53:1-4

Cortés Y, Hormazábal E, Leal H, Urzúa A, Mutis A, Parra L, Quiroz A (2014) Novel antimicrobial activity of a dichloromethane extract obtained from red seaweed Ceramium rubrum (Hudson) (Rhodophyta: Florideophyceae) against Yersinia ruckeri and Saprolegnia parasitica, agents that cause diseases in salmonids. Electron J Biotechnol 17:126-131

Courchesne NM, Parisien A, Wang B, Lan CQ (2009) Enhancement of lipid production using biochemical, genetic and transcription factor engineering approaches. J Biotechnol 141(1-2):31-41

Da Gama B, Plouguerne E, Pereira R (2014) The antifouling defence mechanisms of marine macroalgae. Adv Bot Res 71:414-440

De Brouwer JFC, Stal LJ (2002) Daily fluctuations of exopolymers in cultures of the benthic diatoms Cylindrotheca closterium and Nitzschia sp. (Bacillariophyceae). J Phycol 38:464-472

De Morais MG, Vaz Bda S, de Morais EG, Costa JAV (2015) Biologically active metabolites synthesized by microalgae. Biomed Res Int 2015:835761

Desbois AP, Walton M, Smith VJ (2010) Differential antibacterial activities of fusiform and oval morphotypes of Phaeodactylum tricornutum (Bacillariophyceae). J Mar Biol Assoc U K 90:769-774

Dobretsov S, Abed Raeid MM, Teplitski M (2013) Mini-review: Inhibition of biofouling by marine microorganisms. Biofouling 29(4):423-441

Dugdale TM, Willis A, Wetherbee R (2006) Adhesive modular proteins occur in the extracellular mucilage of the motile, pennate diatom Phaeodactylum tricornutum. Biophys J 90:58-L60

Fernández-Alba AR, Hernando MD, Piedra L, Chisti Y (2002) Toxicity evaluation of single and mixed antifouling biocides measured with acute toxicity bioassays. Anal Chim Acta 456:303-312

Finelli A, Gallant CV, Jarvi K, Burrows LL (2003) Use of in-biofilm expression technology to identify genes involved in Pseudomonas aeruginosa biofilm development. J Bacteriol 185:2700-2710

Fusetani N (2011) Antifouling marine natural products. Nat Prod Rep 28: 400-410

Garcia Camacho F, Gallardo Rodríguez J, Sánchez Mirón A, Cerón García MC, Belarbi EH, Chisti Y, Molina Grima E (2007) Biotechnological significance of toxic marine dinoflagellates. Biotechnol Adv 25:176-194

Gerung G, Lokollo FF, Kusen JD, Harahap AP (2006) Study on the seaweeds of Ambon Island, Indonesia. Coast Mar Sci 30:162-166

Goecke F, Labes A, Weise J, Imhoff JF (2010) Chemical interactions between marine macroalgae and bacteria. Mar Ecol Prog Ser 409: 267-299

Gollasch S (2002) The importance of ship hull fouling as a vector of species introductions into the North Sea. Biofouling 18:105-121

Gorbi S, Bocchetti R, Binelli A, Bacchiocchi S, Orletti R, Nanetti L, Raffaelli F, Vignini A, Accoroni S, Totti C, Regoli F (2012) Biological effects of palytoxin-like compounds from Ostreopsis Cf. ovata: a multibiomarkers approach with mussels Mytilus galloprovincialis. Chemosphere 89:623-632

Gouveia V, Seca AML, Barreto MC, Pinto DCGA (2013) Mini rev. diand sesquiterpenoids from Cystoseira genus: structure, intramolecular transformations and biological activity. Med Chem 13: $1150-1159$

Greff S, Zubia M, Genta-Jouve G, Massi L, Perez T, Thomas OP (2014) Mahorones, highly brominated cyclopentenones from the red alga Asparagopsis taxiformis. J Nat Prod 77:1150-1155

Hamilton M, Haslam R, Napier J, Sayanova O (2014) Metabolic engineering of microalgae for enhanced production of omega-3 long chain polyunsaturated fatty acids. Metab Eng 22:3-9 
Harder T (2008) Marine epibiosis: concepts, ecological consequences and host defence. In: Flemming H-C, Murthy SP, Cooksey K (eds) Marine and industrial biofouling. Springer, Heidelberg

Harder T (2009) Marine epibiosis: concepts, ecological consequences and host defence. Mar Ind Biofouling 4:219-231

Hattab M, Genta-Jouve G, Bouzidi N, Ortalo-Magné A, Hellio C, Maréchal J-P, Piovetti L, Thomas O, Culioli G (2015) Cystophloroketals A-E, unusual phloroglucinol-meroterpenoid hybrids from the brown alga Cystoseira tamariscifolia. J Nat Prod 78: $1663-1670$

Hemalatha A, Mohammed Esa SAR, Suresh M, Thajuddin N, Anantharaman P (2016) Identification of Odontella aurita by rbcl gene sequence - A high antibacterial potential centric marine diatom. Mitochondrial DNA A DNA Mapp Seq Anal 2016:1-7

Hlavová M, Turóczy Z, Bišová K (2015) Improving microalgae for biotechnology - from genetics to synthetic biology. Biotechnol Adv 33: 1194-1203

Jha B, Kavita K, Westphal J, Hartmann A, Schmitt-Kopplin P (2013) Quorum sensing inhibition by Asparagopsis taxiformis, a marine macro alga: separation of the compound that interrupts bacterial communication. Mar Drugs 11:253-265

Kamada T, Vairappan CS (2012) A new bromoallene-producing chemical type of the red alga Laurencia nangii Masuda. Molecules 17:21192125

Kanai Y, Hiroki S, Koshino H, Konoki K, Cho Y, Cayme M, Fukuyo Y, Yotsu-Yamashita M (2011) Identification of novel oxidized levuglandin D in marine red alga and mouse tissue. J Lipid Res 52(12):2245-2254

Kawaguchi S, Hayashizaki K-I (2011) Biodiversity studies on seaweeds and sea grasses in the coastal waters of Southeast Asia (Project-3: Seaweed/ seagrass Group). In: Nishida S, Fortes MD, Miyazaki N (eds) Coastal Marine Science in Southeast Asia - Synthesis Report of the Core University Program of the Japan Society for the Promotion of Science: Coastal Marine Science (2001-2010), pp 49-57

Khozin-Goldberg I, Cohen Z (2011) Unraveling algal lipid metabolism: recent advances in gene identification. Biochemie 93:91-100

Kröger N, Poulsen P (2008) Diatoms- from cell wall biogenesis to nanotechnology. Annu Rev Genet 42:83-107

Ktari L, Ismail-Ben Ali A, Ben Redjem Y, Langar H, El Bour M (2010) Antifouling activity and chemical investigation of the brown alga Dictyota fasciola (Dictyotales) from Tunisian coast. Cah Biol Mar 51:109-115

Lachnit T, Fischer M, Künzel S, Baines J, Harder T (2013) Compounds associated with algal surfaces mediate epiphytic colonization of the marine macroalga Fucus vesiculosus. FEMS Microbiol Ecol 84: $411-420$

Lauritano C, Andersen JH, Hansen E, Albrigtsen M, Escalera L, Esposito F, Helland K, Hanssen KØ, Romano G, Ianora A (2016) Bioactivity Screening of Microalgae for Antioxidant, Anti-Inflammatory, Anticancer, Anti-Diabetes, and Antibacterial Activities. Frontiers in Marine. Science 3:1-12

Li Y, Sommerfeld M, Chen F, Hu Q (2008) Consumption of oxygen by astaxanthin biosynthesis: a protective mechanism against oxidative stress in Haematococcus pluvialis (Chlorophyceae). J Plant Physiol 165:1783-1797

Lind JL, Heimann K, Miller EA, van Vliet C, Hoogenraad NJ, Wetherbee $\mathrm{R}$ (1997) Substratum adhesion and gliding in a diatom are mediated by extracellular proteoglycans. Planta 203:213-221

Ma H, Krock B, Tillmann U, Bickmeyer U, Graeve M, Cembella A (2011) Mode of action of membrane-disruptive lytic compounds from the marine dinoflagellate Alexandrium tamarense. Toxicon $58: 247-258$

Magaletti E, Urbani R, Sist P, Cicero AM (2014) Abundance and chemical characterization of extracellular carbohydrates released by the marine diatom Cylindrotheca fusiformis under N- and P-limitation. Eur J Phycol 39:133-142

Maréchal J-P, Hellio C (2009) Challenges for the development of new non-toxic antifouling solutions. Int J Mol Sci 10:4623-4637

Maréchal J-P, Hellio C (2011) Antifouling activity against barnacle cypris larvae: do target species matter (Amphibalanus amphitrite versus Semibalanus balanoides)? Int Biodeter Biodegr 65:92-101

Mazard S, Penesyan A, Ostrowski M, Paulsen IT, Egan S (2016) Tiny microbes with a big impact: The role of Cyanobacteria and their metabolites in shaping our future. Mar Drugs 14(5):97

Molina-Cárdenas CA, Sánchez-Saavedra MP, Lizárraga-Partida ML (2014) Inhibition of pathogenic Vibrio by the microalgae Isochrysis galbana. J Appl Phycol 26:2347-2355

Molino PJ, Wetherbee R (2008) The biology of biofouling diatoms and their role in the development of microbial slimes. Biofouling 24: 365-379

Montalvaõ S, Demirel Z, Devi P, Lombardi V, Hongisto V, Perälä M, Hattara J, Imamoglu E, Shet Tilvi S, Turan G, Conk Dalay M, Tammela P (2016) Large-scale bioprospecting of cyanobacteria, micro- and macroalgae from the Aegean Sea. Nat Biotechnol 33: 399-406

Mühlroth A, Li K, Røkke G, Winge P, Olsen Y, Hohmann-Marriott MF, Vadstein O, Bones AM (2013) Pathways of lipid metabolism in marine algae, co-expression network, bottlenecks and candidate genes for enhanced production of EPA and DHA in species of Chromista. Mar Drugs 11:4662-4697

Natrah FMI, Muta Harah Z, Japar Sidik B, Izzatul NMS, Syahida A (2015) Antibacterial activities of selected seaweed and seagrass from port Dickson coastal water against different aquaculture pathogens. Sains Malaysiana 44(9):1269-1273

Nguyen VT, Le NH, Lin SM, Steen F, De Clerck O (2013) Checklist of the marine macroalgae of Vietnam. Bot Mar 56:207-227

Orr RJS, Stüken A, Murray SA, Jakobsen KS (2013) Evolution and distribution of saxitoxin biosynthesis in dinoflagellates. Mar Drugs 11:2814-2828

Othmani A, Bouzidi N, Viano Y, Alliche Z, Seridi H, Blache Y, El Hattab M, Briand J-F, Culioli G (2014) Anti-microfouling properties of compounds isolated from several Mediterranean Dictyota spp. J Appl Phycol 26:1573-1584

Othmani A, Bunet R, Bonnefont J, Briand JF, Culioli G (2015) Settlement inhibition of marine biofilm bacteria and barnacle larvae by compounds isolated from the Mediterranean brown alga Taonia atomaria. J Appl Phycol 28:1975-1986

Paradas WC, Tavares Salgado L, Pereira RC, Hellio C, Atella GC, de Lima Moreira D, do Carmo AP, Soares AR, Menezes Amado-Filho G (2016) A novel antifouling defense strategy from red seaweed: exocytosis and deposition of fatty acid derivatives at the cell wall surface. Plant Cell Physiol 57:1008-1019

Pearson L, Mihali T, Moffitt M, Kellmann R, Neilan B (2010) On the chemistry, toxicology and genetics of the cyanobacterial toxins, microcystin, nodularin, saxitoxin and cylindrospermopsin. Mar Drugs 8:1650-1680

Pereira RC, Costa-Lotufo LV (2012) Bioprospecting for bioactives from seaweeds: potential, obstacles and alternatives. Rev Bras Farmacogn 22:894-905

Perez Garcia O, Bashan Y (2015) In: Prokop A, Bajpai RK, Zappi ME (eds) Algal biorefineries Vol. 2: products and refinery design. Springer, Berlin

Persson F, Svensson R, Nylund GM, Fredriksson NJ, Pavia H, Hermansson M (2011) Ecological role of a seaweed secondary metabolite for a colonizing bacterial community. Biofouling 27:579588

Phang S-M, Mustafa EM, Rao Ambati R, Sulaiman NMN, Lim P-E, Majid NA, Dommange X, Schwob C, Liew K-E (2015) Checklist of microalgae collected from different habitats in peninsular 
Malaysia for selection of algal biofuel feedstocks. Malays J Sci 34: $141-167$

Piazza V, Roussis V, Garaventa F, Greco G, Smyrniotopoulos V, Vagias C, Faimali M (2011) Terpenes from the red alga Sphaerococcus coronopifolius inhibit the settlement of barnacles. Mar Biotechnol 13:764-772

Plouguerné E, Hellio C, Cesconetto C, Thabard M, Mason K, Véron B, Pereira RC, Gama BA (2010a) Antifouling activity as a function of population variation in Sargassum vulgare from the littoral of Rio de Janeiro. J Appl Phycol 22:717-724

Plouguerné E, Ioannou E, Georgantea P, Vagias C, Roussis V, Hellio C, Kraffe E, Stiger-Pouvreau V (2010b) Anti-microfouling activity of lipidic metabolites from the invasive brown alga Sargassum muticum (Yendo) fensholt. Mar Biotechnol 12:52-61

Plouguerné E, Cesconetto C, Cruz CP, Pereira RC, da Gama BAP (2012) Within-thallus variation in polyphenolic content and antifouling activity in Sargassum vulgare. J Appl Phycol 24:1629-1635

Poulson KL, Sieg RD, Prince EK, Kubanek J (2010) Allelopathic compounds of a red tide dinoflagellate have species-specific and contextdependent impacts on phytoplankton. Mar Ecol Prog Ser 416:69-78

Poulson-Ellestad K, McMillan E, Montoya JP, Kubanek J (2014) Are offshore phytoplankton susceptible to Karenia brevis allelopathy? J Plankton Res 36:1344-1356

Prince EK, Poulson KL, Myers TL, Sieg RD, Kubanek J (2010) Characterization of allelopathic compounds from the red tide dinoflagellate Karenia brevis. Harmful Algae 10:39-48

Proksch P, Edrada-Ebel RA, Ebel R (2003) Drugs from the sea - opportunities and obstacles. Mar Drugs 1:5-17

Qian P-Y, Xu Y, Fusetani N (2010) Natural products as antifouling compounds: recent progress and future perspectives. Biofouling 26:223234

Qin JG, D'Antignana T, Zhang W, Franco C (2013) Discovery of antimicrobial activities of a marine diatom Thalassiosira rotula. Afr $\mathrm{J}$ Microbiol Res 7:5687-5696

Quijano-Scheggia S (2016) The inhibitory effect of a non-yessotoxinproducing dinoflagellate, Lingulodinium polyedrum (stein) dodge, towards Vibrio vulnificus and Staphylococcus aureus. Rev Biol Trop 64:805-816

Radakovits R, Jinkerson RE, Darzins A, Posewitz MS (2010) Genetic engineering of algae for enhanced biofuel production. Eukaryot Cell 9:486-501

Rajan R, Meena K, Ralraj S, Subramanian G (2015) Studies on the anticorrosive and antifouling properties of the Gracilaria edulis extract incorporated epoxy paint in the Gulf of Mannar coast, Mandapam, India. Prog Org Coat 90:448-454

Ralston E, Swain G (2009) Bioinspiration: the solution for biofouling control? Bioinspir Biomim 4(1):015007

Rolton A, Vignier J, Soudant P, Shumway SE, Bricelj VM, Volety AK (2014) Effects of the red tide dinoflagellate, Karenia brevis, on early development of the eastern oyster Crassostrea virginica and northern quahog Mercenaria mercenaria. Aquat Toxicol 155:199-206

Ruffing AM (2011) Engineered cyanobacteria: teaching an old bug new tricks. Bioeng Bugs 2:136-149

Saburova MA, Polikarpov IG, Burkovsky IV (1995) Spatial structure of an intertidal sandflat microphytobenthic community as related to different spatial scales. Mar Ecol Prog Ser 129:229-239

Saha M, Rempt M, Grosser K, Pohnert G, Weinberger F (2011) Surfaceassociated fucoxanthin mediates settlement of bacterial epiphytes on the rockweed Fucus vesiculosus. Biofouling 27:423-433

Saha M, Rempt M, Gebser B, Grueneberg J, Pohnert G, Weinberger F (2012) Dimethylsulphopropionate (DMSP) and proline from the surface of the brown alga Fucus vesiculosus inhibit bacterial attachment. Biofouling 28:37-41

Saha M, Rempt M, Stratil SB, Wahl M, Pohnert G, Weinberger F (2014) Defence chemistry modulation by light and temperature shifts and the resulting effects on associated epibacteria of Fucus vesiculosus. PLoS One 9(10):e105333

Sala-Pérez M, Alpermann TJ, Krock B, Tillmann U (2016) Growth and bioactive secondary metabolites of arctic Protoceratium reticulatum (Dinophyceae). Harmful Algae 55:85-96

Salta M, Wharton JA, Dennington SP, Stoodley P, Stokes KR (2013) Anti-biofilm performance of three natural products against initial bacterial attachment. Int J Mol Sci 14(11):21757-21780

Scardino AJ, de Nys R (2011) Mini review: biomimetic models and bioinspired surfaces for fouling control. Biofouling 27:73-86

Seed R (1985) Ecological pattern in the epifaunal communities of coastal macroalgae. In: Moore PG, Seed R (eds) The ecology of rocky coasts. Hodder and Stoughton, London, pp 22-35

Selig ER, Turner WR, Troëng S, Wallace BP, Halpern BS, Kaschner K, Lascelles BG, Carpenter KE, Mittermeier RA (2014) Global priorities for marine biodiversity conservation. PLoS One 9(1):e82898

Seth AK, Geringer MR, Hong SJ, Leung KP, Galiano RD, Mustoe TA (2012) Comparative analysis of single-species and polybacterial wound biofilms using a quantitative, in vivo, rabbit ear model. PLoS One 7:e42897

Satheesh S, Ba-akdah MA, Al-Sofyani AA (2016) Natural antifouling compound production by microbes associated with marine macroorganisms - A review. E J Biotech 21:26-35

Sidharthan M, Shin HW, Joo JH (2004) Fouling coverage of a green tide alga, Ulva pertusa on some antifouling test surfaces exposed to Ayagin harbor waters, east coast of South Korea. J Environ Biol 25:39-43

Siless GE, García M, Pérez M, Blustein G, Palermo JA (2017) Largescale purification of pachydictyol a from the brown alga Dictyota dichotoma obtained from algal wash and evaluation of its antifouling activity against the freshwater mollusk Limnoperna fortunei. J Appl Phycol. https://doi.org/10.1007/s10811-017-1261-9

Silkina A, Bazes A, Mouget L, Bourgaugnon N (2012) Comparative efficiency of macroalgal extracts and booster biocides as antifouling agents to control growth of the diatom species. Mar Pollut Bull 64: 2039-2046

Silva GC, Albuquerque-Costa R, Oliveira-Peixoto JR, PessoaNascimento FE, de Macedo-Carneiro PB, Silva dos FernandesVieira RH (2013) Tropical Atlantic marine macroalgae with bioactivity against virulent and antibiotic resistant Vibrio. Lat Am J Aquat Res 41:183-188

Singh R, Kumari P, Reddy C (2015) Antimicrobial compounds from seaweeds-associated bacteria and fungi. Appl Microbiol Biotechnol 99:1571-1586

Sneed JM, Pohnert G (2011a) The green alga Dicytosphaeria ocellata and its organic extracts alter natural bacterial biofilm communities. Biofouling 27:347-356

Sneed JM, Pohnert G (2011b) The green macroalga Dictyosphaeria ocellata influences the structure of the bacterioplankton community through differential effects on individual bacterial phylotypes. FEMS Microbiol Ecol 75:242-254

Soe-Htun U, Wai MK, Nyunt T, Kyaw SPP, Htay YY, Aye MM (2009) Checklist, distribution and potential utilization of marine algae of Myanmar I: Chlorophyta (green algae) and Phaeophyta (brown algae). J Myanmar Acad Arts Sci 7:263-277

Spolaore P, Joannis-Cassan C, Duran E, Isambert A (2006) Commercial applications of microalgae. J Biosci Bioeng 1001:87-96

Srikong W, Mittraparp-arthorn P, Rattanaporn O, Bovornreungroj N, Bovornreungroj P (2015) Antimicrobial activity of seaweed extracts from Pattani, Southeast coast of Thailand. Food Appl Biosci J 3:3949

Staats N, De Winder B, Stal LJ, Mur LR (1999) Isolation and characterization of extracellular polysaccharides from the epipelic diatoms Cylindrotheca closterium and Navicula salinarum. Eur J Phycol 34:161-169 
Sumper M, Brunner E (2008) Silica biomineralisation in diatoms: the model organism Thalassiosira pseudonana. Chem Bio Chem 9: 1187-1194

Sun Y-Y, Wang H, Guo G-1, Pu Y-F, Yan B-L, Wang C-H (2015) Green alga Ulva pertusa - a new source of bioactive compounds with antialgal activity. Environ Sci Pollut Res 22:10351-10359

Thabard M, Gros O, Hellio C, Maréchal JP (2011) Sargassum polyceratium (Phaeophyceae, Fucaceae) surface molecule activity towards fouling organisms and embryonic development of benthic species. Bot Mar 54:147-157

Thompson SEM, Taylor AR, Brownlee C, Callow ME, Callow JA (2008) The role of nitric oxide in diatom adhesion in relation to substratum properties. J Phycol 44:967-976

Todd PA, Ong X, Chou LM (2010) Impacts of pollution on marine life in Southeast Asia. Biodivers Conserv 19:1063-1082

Ugoala E, Ndukwe GI, Mustapha KB, Ayo RI (2012) Contraints to large scale algae biomass production and utilization. J Algal Biomass Uth 3:14-32

Umezawa T, Oguri Y, Matsuura H, Yamazaki S, Suzuki M, Yoshimura E, Furuta T, Nogata Y, Serisawa Y, Matsuyama-Serisawa K, Abe T, Matsuda F, Suzuki M, Okino T (2014) Omaezallene from red alga Laurencia sp.: structure elucidation, total synthesis, and antifouling activity. Angew Chem 53:3909-3912

Vairappan CS, Suzuki M, Ishii T, Okino T, Abe T, Masuda M (2008) Antibacterial activity of halogenated sesquiterpenes from Malaysian Laurencia spp. Phytochemistry 69(13):2490-2494

Van Alstyne KL, Harvey EL, Cataldo M (2014) Effects of dopamine, a compound released by the green-tide macroalga Ulvaria obscura (Chlorophyta), on marine algae and invertebrate larvae and juveniles. Phycologia 53:195-202

Vanelslander B, Paul C, Grueneberg J et al (2012) Daily bursts of biogenic cyanogen bromide $(\mathrm{BrCN})$ control biofilm formation around a marine benthic diatom. Proc Nat Acad Sci 109:2412-2417

Vardi A, Bidle KD, Kwityn C, Hirsh DJ, Thompson SM, Callow JA, Falkowski P, Bowler C (2008) A diatom gene regulating nitricoxide signaling and susceptibility to diatom-derived aldehydes. Curr Biol 18:895-899

Wafar M, Venkataraman K, Ingole B, Ajmal Khan S, LokaBharathi P (2011) State of knowledge of coastal and marine biodiversity of Indian Ocean countries. PLoS One 6:e14613

Wahl M (1989) Marine epibiosis. I. Fouling and antifouling: some basic aspects. Mar Ecol Prog Ser 58:175-189
Wahl M (2008) Ecological lever and interface ecology: epibiosis modulates the interactions between host and environment. Biofouling 24 : 427-438

Wahl M (2009) Epibiosis : ecology, effects and defences sessile mode of life. In: Wahl M (ed) Marine hard bottom communities. Springer, Cham pp 61-72

Wahl M, Shahnaz L, Dobretsov S, Saha M, Symanowski F, David K, Lachnit T, Vasel M, Weinberger F (2010) Ecology of antifouling resistance in the bladder wrack Fucus vesiculosus: patterns of microfouling and antimicrobial protection. Mar Ecol Prog Ser 411: $33-48$

Wahl M, Goecke F, Labes A, Dobretsov S, Weinberger F (2012) The second skin: ecological role of epibiotic biofilms on marine organisms. Front Microbiol 3:292

Waite JH, Tanzer ML (1981) Polyphenolic substance of Mytilus edulis: novel adhesive containing L-Dopa and hydroxyproline. Science 212:1038-1040

Webb CO, Slik JWF, Triono T (2010) Biodiversity inventory and informatics in Southeast Asia. Biodivers Conserv 19:955-972

Wijesinghe WA, Kim EA, Kang MC, Lee WW, Lee HS, Vairappan CS, Jeon YJ (2014) Assessment of antiinflammatory effect of $5 \beta$ hydroxypalisadin B isolated from red seaweed Laurencia snackeyi in zebrafish embryo in vivo model. Environ Toxicol Pharmacol 37(1):110-117

Wijffels RH (2007) Potential of sponges and microalgae for marine biotechnology. Trends Biotechnol 26:26-31

Willis A, Eason-Hubbard M, Hodson O, Maheswari U, Bowler C, Wetherbee R (2014) Adhesion molecules from the diatom Phaeodactylum tricornutum (Bacillariophyceae): genomic identification by amino-acid profiling and in vivo analysis. J Phycol 50: 837-849

Wustman BA, Gretz MR, Hoagland KD (1997) Extracellular matrix in diatoms (Bacillariophyceae). A model of adhesives based on chemical characterization and localization of polysaccharides from the marine diatom Achnanthes longipes and other diatoms. Plant Physiol 133:1059-1069

Yamada KM, Geiger B (1997) Molecular interactions in cell adhesion complexes. Curr Opin Cell Biol 9:76-85

Zhao H, Waite JH (2006) Linking adhesive and structural proteins in the attachment plaque of Mytilus californianus. J Biol Chem 281: 26150-26158 